\title{
Profile and performance of nutritionists in Primary Health Care
}

\author{
Perfil e atuação de nutricionistas na \\ Atenção Primária à Saúde
}

Dixis FIGUEROA PEDRAZA

Iná da Silva SANTOS²

\section{A B S T R A C T}

\section{Objective}

To describe the profile and performance of nutritionists in Primary Health Care.

\section{Methods}

A cross-sectional study was carried out, and all nutritionists in two municipalities of Paraiba, Brazil, were interviewed. Information was collected through structured interviews on demographic characteristics, professional qualification, development of food and nutrition activities, knowledge and use of essential bibliography for the work in Primary Care.

\section{Results}

In one municipality there were 28 teams of the Family Health Strategy and in the other, nineteen teams. In all, nineteen nutritionists were interviewed, fourteen of whom were working in the health teams and five were working exclusively in the Family Health Support Centers. All but one were women and the majority were between 20 and 39 years; the majority $(n=10)$ had no graduate training. Nutritionists from the basic health teams developed more public health nutrition actions, such as defining nutritional care protocols and vitamin A and iron supplementation than those from the Family Health Support Centers (11 versus 1; and 13 versus 1 , respectively). About half were satisfied with work in general, and dissatisfaction was related to deficiencies in the availability and quality of anthropometric equipment, physical structure and material.

\section{Conclusion}

Nutritionists work in food and nutrition actions in collective health, emphasizing the importance of qualification and practices that better combine the programmatic agenda of this area with Primary Care.

Keywords: Employer performance appraisal. Nutrition, public health. Primary health care.

\footnotetext{
1 Universidade Estadual da Paraíba, Centro de Ciências Biológicas e da Saúde, Programa de Pós-Graduação em Saúde Pública. R. Baraúnas, 351, Bairro Universitário, 58429-500, Campina Grande, PB, Brasil. Correspondência para/Correspondence to: D FIGUEROA PEDRAZA. E-mail: <dixisfigueroa@gmail.com>.

2 Universidade Federal Pelotas, Faculdade de Medicina, Programa de Pós-Graduação em Epidemiologia. Pelotas, RS, Brasil. Support: Conselho Nacional de Desenvolvimento Científico e Tecnológico (Process no 476520/2013-4) and Fundação de Apoio à Pesquisa do Estado da Paraíba (Process no 37/13).
} 


\section{RE S U M O}

\section{Objetivo}

Descrever o perfil e a atuação de nutricionistas na Atenção Primária à Saúde.

\section{Métodos}

Estudo transversal, tendo sido entrevistados todos os nutricionistas em atividade em dois municípios da Paraiba, por ocasião da pesquisa. Foram coletadas informações sobre características demográficas, qualificação profissional, desenvolvimento de ações de alimentação e nutrição, conhecimento e utilização de bibliografia essencial para o trabalho na Atenção Básica, por meio de entrevistas estruturadas.

\section{Resultados}

Em um município atuavam 28 equipes da Estratégia Saúde da Família e no outro, 19. Ao todo, foram entrevistados 19 nutricionistas, 14 dos quais desenvolviam atividades nas equipes de saúde e 5, exclusivamente nos Núcleos de Apoio à Saúde da Família. Todos, exceto um, eram mulheres e a maioria tinha entre 20 e 39 anos de idade; a maioria $(n=10)$, sem formação de pós-graduação stricto ou lato sensu. Nutricionistas das equipes básicas de saúde desenvolviam mais ações de nutrição em saúde pública, como definição de protocolos de atenção nutricional e suplementação de vitamina $A$ e ferro do que os dos Núcleos de Apoio à Saúde da Família (11 versus 1; e 13 versus 1, respectivamente). Cerca da metade estava satisfeita com o trabalho em geral, sendo a insatisfação relacionada a deficiências na disponibilidade e qualidade de equipamentos antropométricos, estrutura física e material de consumo.

\section{Conclusão}

Os nutricionistas atuam em ações de alimentação e nutrição em saúde coletiva, ressaltando-se a importância de qualificação e práticas que dialoguem melhor com a agenda programática da área com a Atenção Básica.

Palavras-chave: Avaliação de desempenho profissional. Nutrição em saúde pública. Atenção primária à saúde.

\section{INTRODUCTION}

Primary Health Care (PHC), also called Basic Care in Brazil, is the first level of contact of individuals, families and communities with national health systems, and has been designed to address the main health needs of communities, through actions of promotion, prevention, treatment and rehabilitation, both individually and collectively [1]. In Brazil, the Family Health Strategy (FHS) was adopted as a structuring model of Primary Care [2].

The Brazilian Ministry of Health establishes that teams working in the FHS are multidisciplinary and composed of at least a general practitioner or specialist in Family Health or a Family and Community physician; a general nurse or specialist in Family Health; a nursing technician or assistant; and community health workers [3]. However, evaluative research on FHS has pointed to limitations that include hegemonic and disarticulated actions that impair the comprehensiveness of care [4]. At this context, the Family Health Support Center (FHSC) was established with the objective of supporting and expanding the actions developed in the FHS with the inclusion of professionals from other areas of knowledge [5].

With the perspective of increasing the resolution and impact on the health situation of people and communities [3], the nutrition area in PHC should include the development of strategies to respond to the main demands associated with eating disorders, nutritional deficiencies, malnutrition and obesity; development of therapeutic projects; food and nutrition diagnosis of the population; promotion of food and nutrition safety; and definition of nutritional care protocols [6]. In this sense, the nutritionist is considered the only professional with adequate training to act in the promotion of healthy food practices and food and nutrition safety, effecting the promotion and recovery of health and the prevention of diseases [7]. However, the insertion of this professional is still incipient in Brazil [7-9]. 
Currently, only $17.5 \%$ of the FHS teams have a nutritionist and $21.8 \%$ have a matrix support of this professional through FHSC $[10,11]$. The presence of this professional in these scopes, however, has shown a positive evolution over the years [12], becoming eminent the need to reveal aspects of these workers as possible drivers of transformation of health practices [13].

The purpose of this study was to characterize the profile and performance of nutritionists working in $\mathrm{PHC}$.

\section{METHO D S}

A cross-sectional study was carried out with nutritionists from FHS and FHSC teams in two municipalities in the state of Paraiba, Brazil which are similar as to the geographical location (located in the metropolitan region of the state capital, with access to the network of services available there), degree of urbanization (almost 100\%), demographic and social indicators (index of human development at medium level 0.748 in one of the municipalities and 0.649 in the other) and organization of Primary Health Services (population coverage of the FHS of about $100 \%$ ). In each municipality, all active nutritionists were included in the study.

Data collection took place in the facilities of health units, between July and December of 2014, being carried out by professionals and students of the health area, under the supervision of the research coordinator. The quality control of the study included training and standardization of the interviewers, construction of an instructions manual for application of the questionnaires and conducting a pilot study in another municipality of Paraíba.

Theinformation wasobtained byinterview, using a structured questionnaire with closed questions that approached demographic and labor characteristics; professional qualification; professional practices and developed actions on food and nutrition; knowledge and use of bibliographic sources essential to the development of food and nutrition actions; and job satisfaction. Demographic characteristics included gender, age, marital status (whether living with or without partner) and whether they had children. Investigated labor characteristics included information about type of bond, existence of another job, weekly workload and perception about remuneration. Professional qualification included the completion of a graduate course (training aimed at working in $\mathrm{PHC}$ ). The description of professional practices included home visits, individual care, therapeutic group, population training, bureaucratic tasks, team meetings, community meetings and meetings with the central level of the health secretariat.

Investigated actions on food and nutrition were based on the programmatic agenda of care of PHC, referring to the area of food and nutrition, as recommended by the Ministry of Health $[6,8,14,15]$. The actions contemplated, applicable to both nutritionists who work in the FHS and FHSC teams, were: food and nutrition diagnosis; preparation, revision, adaptation, standardization and definition of nutritional care protocols; promotion of breastfeeding and healthy complementary feeding; promotion of healthy eating; diagnosis and identification of children at nutritional risk; food and nutrition surveillance with the use of food consumption data; Food and nutrition surveillance using anthropometric data; use of Sistema de Vigilância Alimentar e Nutricional (Sisvan) epidemiological data; activities linked to the vitamin A supplementation program; activities linked to the iron supplementation program; nutritional care for children with malnutrition or nutritional risk; nutritional care for overweight children; nutritional care for children with specific nutritional needs (inborn errors of metabolism, celiac disease, HIV/AIDS, food intolerances, food allergies, eating disorders, prematurity and nephropathies); monitoring the nutritional status of children benefiting from the Family Grant Federal Program; monitoring of the Family 
Grant Federal Program's health conditions; monitoring the nutritional status of children in the School Health Program; evaluation of the results of food and nutrition actions and their readjustment. These actions were investigated one by one through an introductory question stating: "Do you participate in the development of the following food and nutrition actions?"

Knowledge and use of bibliographic sources essential for the development of food and nutrition actions are related to the following (all available on the Brazilian Ministry of Health website at http://portal.saude.gov.br/): National Food And Nutrition Policy, National Primary Care Policy, National Health Promotion Policy, Matrix of food and nutrition actions in Primary Care, Food and Nutrition Surveillance System Protocols - Sisvan, FHSC Guidelines: Food Guide for the Brazilian population, Food Guide for children under two years old, General conducts Manual of National Vitamin A Supplementation Program, Operational Manual of National Iron Supplementation Program and Manual of orientations about the Family Grant Federal Program in Health. Knowledge and use of these sources was investigated by initially asking "Do you know the following technical materials/ standards/protocols related to food and nutrition actions?" If so, the interviewer proceed "Do you use this material?" Answers were categorized in three groups: "I know and I use"; "I know but I do not use"; and "I do not know". The categories "I know but I do not use" and "I do not know were grouped for analysis".

Satisfaction with work was related to the following aspects: physical structure, availability of material, availability and quality of equipment, link with the central level of the health secretariat, relationship among team members, relationship with the community and general satisfaction with work. The answers included three alternatives: satisfied, partially satisfied and dissatisfied. The partially satisfied and dissatisfied categories were grouped for analysis.
The collected data were organized in spreadsheets and typed in double entry. The validate application of the Epi Info software (Centers of Disease Control and Prevention, Atlanta, Georgia, United States) version 3.3.2 was used to analyze the consistency of the data. Descriptive analysis was carried out with frequency measures of the variables. Subsequently, the proportions found between the two work insertions of the nutritionist (FHS or FHSC teams) were compared using Fischer's test. The level of significance used to evaluate the differences in parameters was 5\%. The analyzes were performed using Stata software (Stata Corporation, College Station, Texas, United States) version 12.0.

The research was approved by the Research Ethics Committee of the Universidade Estadual da Paraíba (Protocol $\mathrm{n}^{\circ}$ 19689613.3.0000.5187). All the participants of the research signed the Free and Informed Consent Form.

\section{RES U L T S}

In one of the municipalities there were 28 FHS teams and in the other, nineteen FHS teams. In all, nineteen nutritionists were interviewed, fourteen of whom were working in health teams and five exclusively in the FHSC. There were no refusals to participate in the study.

Only one of the nutritionists was male, the majority were between 20 and 39 years of age $(n=11)$, had no children $(n=14)$ and had not undergone graduate studies $(n=10)$. Ten nutritionists were hired, nine had another job and fourteen perceived the payment as inadequate. Regarding professional practices, meetings with the community were the least mentioned. The majority $(n=17)$ performed bureaucratic tasks, such as filling forms. Training to work on PHC and child health care was reported by nine of the professionals, while ten said they had received training in the National Food and Nutrition Policy or in food and nutrition actions in PHC. There 
was a higher proportion of nutritionists who received these trainings among those working in the FHS teams compared to those working in the FHSC (Table 1).

Food and nutrition actions developed by the nutritionists are shown in Table 2 . Most nutritionists reported performing food and nutrition actions advocated for PHC, with emphasis on practices for promoting eating habits, diagnosis and care for nutritional deviations. However, community diagnosis $(n=6)$, activities in the context of the vitamin A supplementation program $(n=5)$ and the iron supplementation program $(n=5)$ presented higher frequencies of negative answers. Differences were observed in the development of some food and nutrition actions, with a better situation among nutritionists of FHS teams: elaboration, revision, adaptation, standardization and definition of nutritional care protocols $(p=0.038$ ),

Table 1. Profile and characteristics of the performance of Primary Health Care (PHC) nutritionists in two municipalities of Paraiba, Brazil, 2014

\begin{tabular}{|c|c|c|c|c|}
\hline \multirow{2}{*}{ Variable } & \multirow{2}{*}{ Total (n) } & \multicolumn{2}{|c|}{ Place of performance } & \multirow{2}{*}{$p$} \\
\hline & & FHS (n) & FHSC (n) & \\
\hline \multicolumn{5}{|c|}{ Demographic characteristics } \\
\hline Gender & & & & 0.737 \\
\hline Female & 18 & 13 & 5 & \\
\hline Male & 1 & 1 & 0 & \\
\hline Age (years) & & & & 0.664 \\
\hline 20 to 29 & 6 & 4 & 2 & \\
\hline 30 to 39 & 5 & 4 & 1 & \\
\hline 40 to 49 & 8 & 6 & 2 & \\
\hline Children (yes) & 5 & 4 & 1 & 0.603 \\
\hline \multicolumn{5}{|c|}{ Qualification characteristics } \\
\hline Graduate studies in public health/family health/maternal and child health & 9 & 8 & 1 & 0.184 \\
\hline Training to work in $\mathrm{PHC}$ & 9 & 9 & 0 & 0.022 \\
\hline Training to work on child's health care & 9 & 9 & 0 & 0.022 \\
\hline Training in PNAN or food and nutrition actions in $\mathrm{PHC}$ & 10 & 10 & 0 & 0.011 \\
\hline \multicolumn{5}{|c|}{ Labor characteristics } \\
\hline Employment relationship (civil servant) & 9 & 6 & 3 & 0.444 \\
\hline Having another job (yes) & 9 & 5 & 4 & 0.119 \\
\hline Weekly load (hours) & & & & 0.084 \\
\hline 40 & 14 & 12 & 2 & \\
\hline 20 & 5 & 2 & 3 & \\
\hline Adequate remuneration (yes) & 5 & 5 & 0 & 0.172 \\
\hline \multicolumn{5}{|c|}{ Profissional practices } \\
\hline Home visit & 19 & 14 & 5 & 1.000 \\
\hline Individual care & 19 & 14 & 5 & 1.000 \\
\hline Therapeutic group & 13 & 10 & 3 & 0.520 \\
\hline Bureaucratic tasks & 17 & 12 & 5 & 0.532 \\
\hline Team meetings & 18 & 14 & 4 & 0.263 \\
\hline Community meetings & 8 & 7 & 1 & 0.267 \\
\hline Meetings with the central level of the health secretariat & 15 & 10 & 5 & 0.258 \\
\hline
\end{tabular}

Note: FHS: Family Health Strategy; FHSC: Family Health Support Center; PNAN: Política Nacional de Alimentação e Nutrição (National Food and Nutrition Policy). 
use of Sisvan epidemiological data $(p=0.010)$, development of actions in the context of vitamin A supplementation program $(p=0.006)$ and the iron supplementation program $(p=0.006)$ and follow-up of the Family Grant Federal Program's health conditions $(p=0.001)$.

The Family Health Support Center Guidelines $(n=13)$, the Matrix of food and nutrition actions in Primary Care $(n=10)$ and the National Primary Care Policy $(n=6)$ were the bibliographic sources with the highest frequencies of answers "I know but I do not use it/do not know". Regarding specific materials of the nutrition area, almost all nutritionists reported knowing and using them. Professionals from the FHS teams reported higher frequencies of knowing and using the National Primary Care Policy, the National Health Promotion Policy, the Food and Nutrition Surveillance System Protocols - Sisvan, the General conducts Manual of National Vitamin
A Supplementation Program and the Guidance Manual on the Family Grant Program in Health (Table 3).

When asked aboutjobsatisfaction, only two nutritionists indicated general dissatisfaction. Most were not satisfied with the availability and quality of anthropometric equipment, physical structure and material. The relationship with the community and with team members was positively assessed by most professionals (Table 4).

\section{DISCUSSION}

This study described the profile and performance of nutritionists allocated in basic units of the FHS or members of the FHSC in two municipalities of Paraiba. Regarding the demographic profile, the predominance of female

Table 2. Food and nutrition actions developed by Primary Health Care nutritionists in two municipalities of Paraiba, Brazil, 2014.

\begin{tabular}{|c|c|c|c|c|}
\hline \multirow{2}{*}{ Activities developed } & \multirow{2}{*}{ Total $(n)$} & \multicolumn{2}{|c|}{ Place of performance } & \multirow{2}{*}{$p$} \\
\hline & & FHS (n) & FHSC (n) & \\
\hline Food and nutrition diagnosis with identification of vulnerable areas and risk groups. & 13 & 11 & 2 & 0.262 \\
\hline $\begin{array}{l}\text { Elaboration, revision, adaptation, standardization and definition of nutritional care } \\
\text { protocols. }\end{array}$ & 12 & 11 & 1 & 0.038 \\
\hline $\begin{array}{l}\text { Encouraging, supporting and protecting breastfeeding and healthy complementary } \\
\text { feeding. }\end{array}$ & 19 & 14 & 5 & 1.000 \\
\hline Promotion of healthy eating. & 19 & 14 & 5 & 1.000 \\
\hline Diagnosis and identification of children at nutritional risk. & 18 & 14 & 4 & 0.263 \\
\hline Food and nutritional surveillance using food consumption data. & 15 & 12 & 3 & 0.272 \\
\hline Food and nutritional surveillance using anthropometric data. & 17 & 14 & 3 & 0.058 \\
\hline Use of epidemiological data from Sisvan. & 16 & 14 & 2 & 0.010 \\
\hline Development of actions in the context of the vitamin A supplementation program. & 14 & 13 & 1 & 0.006 \\
\hline Development of actions in the context of the iron supplementation program. & 14 & 13 & 1 & 0.006 \\
\hline Nutritional care for children with malnutrition or at nutritional risk. & 19 & 14 & 5 & 1.000 \\
\hline Nutritional care for overweight children. & 19 & 14 & 5 & 1.000 \\
\hline Nutritional care for children with specific nutritional needs. & 17 & 14 & 3 & 0.058 \\
\hline Follow-up of the nutritional status of children benefited by the Family Grant Program. & 17 & 14 & 3 & 0.058 \\
\hline Follow-up of the health conditions of the Family Grant Program. & 15 & 14 & 1 & 0.001 \\
\hline Follow-up of the nutritional status of children in the School Health Program. & 17 & 13 & 4 & 0.468 \\
\hline Evaluation of the results of food and nutrition actions, re-adjusting them if necessary. & 16 & 11 & 5 & 0.530 \\
\hline
\end{tabular}

Note: FHS: Family Health Strategy; FHSC: Family Health Support Center; Sisvan: Sistema de Vigilância Alimentar e Nutricional (Food and Nutrition Surveillance System). 
Table 3. Knowledge and use of materials needed to develop food and nutrition actions by Primary Health Care nutritionists in two municipalities of Paraíba, Brazil, 2014.

\begin{tabular}{lcccc}
\hline \multirow{2}{*}{ Materials you know and use } & Total (n) & Place of performance & p \\
\cline { 2 - 4 } National Food and Nutrition Policy & 16 & 13 & 3 & 0.155 \\
National Primary Care Policy & 13 & 12 & 1 & 0.017 \\
National Health Promotion Policy & 15 & 13 & 2 & 0.037 \\
Matrix of food and nutrition actions in Primary Care & 9 & 8 & 1 & 0.184 \\
Food and Nutrition Surveillance System Protocols & 16 & 14 & 2 & 0.010 \\
FHSC Guidelines: Family Health Support Center & 6 & 3 & 3 & 0.262 \\
Food Guide for the Brazilian Population & 16 & 13 & 3 & 0.155 \\
Food Guide for children under two years old & 18 & 14 & 4 & 0.263 \\
Manual of general conduct of the National Vitamin A Supplementation Program & 16 & 14 & 2 & 0.010 \\
Operational Manual of the National Iron Supplementation Program & 14 & 12 & 2 & 0.084 \\
Handbook of Guidelines on the Family Grant Federal Program in health & 15 & 14 & 1 & 0.001 \\
\hline
\end{tabular}

Note: FHS: Family Health Strategy; FHSC: Family Health Support Center.

Table 4. Satisfied with work of Primary Health Care nutritionists in two municipalities of Paraiba, Brazil, 2014.

\begin{tabular}{lcccc}
\hline \multirow{2}{*}{ Satisfied with work } & Total $(\mathrm{n})$ & \multicolumn{2}{c}{ Place of performance } & $p$ \\
\cline { 3 - 4 } & & FHS $(\mathrm{n})$ & FHSC $(\mathrm{n})$ & 0 \\
Physical structure & 6 & 6 & 1 & 0.111 \\
Availability of materials & 7 & 6 & 0 & 0.366 \\
Availability and quality of anthropometric equipment & 3 & 3 & 1 & 0.119 \\
Bond with the central level of the Health Secretariat & 10 & 9 & 5 & 0.376 \\
Relationship between team members & 16 & 11 & 4 & 0.728 \\
Relationship with the community & 15 & 11 & 1 & 0.071 \\
General satisfied with work & 11 & 10 & & \\
\hline
\end{tabular}

Note: FHS: Family Health Strategy; FHSC: Family Health Support Center.

nutritionists and in the age groups between 20-39 years is comparable to that verified in other studies, which revealed the feminization of the profession and the performance of young adults $[9,16-18]$. This profile may be related to the cultural connotation, in Brazil, of the role of women as caregivers [19] and the short time of existence of the profession [16].

The small number of nutritionists, especially those enrolled in FHSC, who indicated having participated in training to work in the $\mathrm{PHC}$, in the nutrition actions directed to the Primary Care and in the child's health converges with previous reports [18-20]. However, complementary analyzes of the current study did not identify differences in the knowledge of technical materials nor in the performance of actions of the nutrition area among those with and without graduate courses (data not shown). The training of the nutritionist directed to PHC is essential to minimize the difficulties of articulation between teaching and health service of the undergraduate courses in Nutrition [21]. The lack of training may be related to the precarious and temporary contracting of nutritionists, which, in turn, may lead them to exercise the profession in other places or areas of activity, characteristics found both in this (nine had another employment relationship) and in other studies $[18,20]$. Negative consequences may arise from these labor characteristics, such 
as demotivation and turnover of professionals, difficulties in permanent education processes, weak bonds with the population and with the health team, and discontinuity of actions, which may impair the effectiveness of the FHS $[18,20]$.

In the professional practices, the results of the present study emphasize that home visit and individual care are consolidated activities, while community orientation of the actions was less frequent. These findings are in agreement with those of previous researches $[9,16,22]$ and are indicative of a fragmented work process that is focused on actions at the individual level and restricted to the physical limits of the health unit, as previously mentioned [18]. It is important to emphasize that at the family and community level, established as a priority in the nutritionist's role in Primary Care, the development of nutritional care protocols and the participation of therapeutic plans may represent an excellent opportunity for interdisciplinary practices suitable for identifying risk situations, recognition of the territory and interaction with other levels of care [23].

With regard to food and nutrition actions, nutritionists proved to be involvement with them, both at the level of care and of health promotion. These results, in addition to reflecting the importance of the nutritionist to the development of the activities that are inherent to them $[16,17]$, show the simultaneous presence of the traditional biomedical model of care and the model based on health promotion and prevention of diseases, as suggested in another study [22]. Despite the epidemiological relevance of nutritional deficiencies of iron and vitamin $A$ $[6,14]$, five nutritionists answered they did not to develop actions within the supplementation programs with these micronutrients. This situation is worrying, since the absence of guidance and support from professionals in the health service can lead to problems of adherence to supplementation. In this sense, the importance of training and motivating professionals is highlighted, in addition to the link between these and the community and the global vision of nutritional deficiency [24]. Other data that deserve attention is the performance of only 13 of the 19 professionals in the food and nutrition diagnosis and the non-use of Sisvan data by FHSC professionals was identified, distancing themselves from the Primary Care programmatic agenda regarding food and nutrition actions and with harm to planning, follow-up and evaluation of these actions [6].

Regarding the bibliographic sources, those that are specific and exclusive to the nutrition area were better known and used than those directed to work in PHC. Similarly, a previous study found that most nutritionists are familiar with the Food Guide for the Brazilian Population, the Food and Nutrition Surveillance Protocol, and the National Food and Nutrition Policy, but there are few who know the Matrix of food and nutrition actions in Primary Care [21]. The proper use of these materials enables the correct diagnosis of the nutritional status and the identification of associated risks [25]. Problems related to the use of technical documents in the PHC framework were similarly pointed out in previous studies addressing their use by health professionals in different scenarios and objectives [25-28]. The adequate use of these technologies is fundamental to the standardization and systematization of care, enabling a multidisciplinary, comprehensive, more qualified and effective care [25-27].

The lack of working conditions in relation to infrastructure, anthropometric equipment, resources for the development of daily activities, including those related to food and nutrition, found in a recent study with nurses, physicians and nutritionists of FHS teams [17], coincides with the main factors highlighted in this study. Difficulties related to the infrastructure of health facilities, including anthropometric equipment, were also highlighted in a literature review on growth surveillance in the country's Primary Health Care network [25]. Data from the year 
2012 showed that in $17.0 \%, 20.3 \%, 34.7 \%$ and $49.1 \%$ of the Primary Health Care Units of the country there are, respectively, no children's scales, $150 \mathrm{~kg}$ scales, anthropometric rules and anthropometers in conditions of use [29]. Lack of structure hinders the development of food and nutrition actions, motivation for work, the process of permanent education and the performance of the system $[20,25]$. On the other hand, satisfaction of the professionals of this study in the scope of human relations can generate commitment, supporting the decisionmaking and promoting co-responsibility for health status [30].

The results of the present study showed that professionals of the family health teams presented better mastery of materials in the area of nutrition in collective health, as well as greater involvement with nutrition actions than the professionals inserted in FHSC. These findings may be related to several factors. Firstly, explanations related to the intentional choice of the municipalities must be considered, since one of them has a work model that includes, since 2001, the insertion of nutritionists in the minimum FHS team and the development of food and nutrition actions in an articulated way, as an essential component of care. In this study, nutritionists included in the FHS teams were represented professionals more qualified to work, which seems to contribute positively in the field of the technical documents indispensable for the exercise of the profession and in the development of food and nutrition actions, in similar conditions to academic education. Because they represent more recent alternatives of professional performance, the difficulties that the nutritionist faces in the construction of his/her practice in the $\mathrm{PHC}$ are possibly more accentuated among professionals of FHSC.

Despite the statistical validity, it should be emphasized that the previous differences do not necessarily express higher qualification of one group in relation to the other, since the number of the professionals inserted in
FHSC involved in the study was very small and the groups are represented by professionals with specific attributions. It is incumbent upon FHSC nutritionists to provide matrix support to Primary Care teams for the expansion and improvement of care through interdisciplinary work, with experiences that have shown difficulties related to understanding the role of the FHSC and matrix support, as well as the development of activities of articulated form $[9,18,23]$. According to the FHSC creation, food and nutrition actions should be directed toward the promotion of healthy eating and attending to the greatest care needs [5], however, it seems to be an important reflection on this action so that professionals can structure processes with less individualizing and technicist practices [9].

This study contemplated only the answers of the professionals themselves, which may have implicit information bias. Also, the information refers to professionals inserted in the reality of two municipalities, exclusively, of a single Brazilian state, with limitations as to the generalization power of the results. Among the advantages, all nutritionists working in the Primary Care of the two municipalities were included. In addition, the data were collected in an active and standardized manner, through interview, which prevents loss of information. Also, there were no refusals to participate in the interviews. However, results should be interpreted with caution due to the low number of FHSC nutritionists who participated in the research.

\section{CONCLUSION}

Nutritionists in FHS and FHSC teams work on actions of the food and nutrition programmatic agenda in PHC, including health promotion practices. Nutritionists' qualification and performance need a greater dialogue and interaction between food and nutrition area and PHC. Professional dissatisfaction is centered mainly on structural aspects. These findings 
may help in the organization of health teams by pointing out weaknesses that need to be overcome.

\section{CONTRIBUTORS}

D FIGUEROA PEDRAZA contributed to the design, analysis and interpretation of data; essay writing and critical review of intellectual content; final approval of the version to be published. IS SANTOS contributed to the interpretation of the data; critical review of intellectual content; final approval of the version to be published.

\section{REFERE NCES}

1. Organização Mundial da Saúde. Conferência Internacional sobre Cuidados Primários de Saúde: Declaração de Alma-Ata, 1978. Brasília: Ministério da Saúde; 2004.

2. Motta LCS, Siqueira-Batista R. Estratégia saúde da família: clínica e crítica. Rev Bras Educ Med. 2015;39(2):196-207. https://doi.org/10.1590/19 81-52712015v39n2e00912014

3. Ministério da Saúde (Brasil). Política Nacional de Atenção Básica. Brasília: Ministério da Saúde; 2012.

4. Silva LA, Casotti CA, Chaves SCL. A produção científica brasileira sobre a Estratégia Saúde da Família e a mudança no modelo de atenção. Ciênc Saúde Coletiva. 2013;18(1):221-32. https:// doi.org/10.1590/S1413-81232013000100023

5. Ministério da Saúde (Brasil). Portaria $n^{\circ} 154$, de 24 de janeiro de 2008. Cria os Núcleos de Apoio à Saúde da Família - NASF. Diário Oficial da União. 2008; 24 jan.

6. Jaime $P C$, Silva $A C F$, Lima $A M C$, Bortolini GA. Ações de alimentação e nutrição na atenção básica: a experiência de organização no Governo Brasileiro. Rev Nutr. 2011;24(6):809-24. https:// doi.org/10.1590/S1415-52732011000600002

7. Geus LMM, Maciel CS, Burda ICA, Daros SJ, Batistel S, Martins TCA, et al. A importância na inserção do nutricionista na Estratégia Saúde da Família. Ciênc Saúde Coletiva. 2011;16(Supl.1):797-804. https:// doi.org/10.1590/S1413-81232011000700010

8. Ministério da Saúde (Brasil). Matriz de ações de alimentação e nutrição na Atenção Básica à Saúde. Séria A. Normas e Manuais Técnicos. Brasília: Ministério da Saúde; 2009.
9. Rodrigues DCM, Bosi MLM. O lugar do nutricionista nos Núcleos de Apoio à Saúde da Família. Rev Nutr. 2014;27(6):735-46. https://doi. org/10.1590/1415-52732014000600008

10. Ministério da Saúde (Brasil). Gestão da Atenção Básica: características das Unidades Básicas de Saúde. Retratos da Atenção Básica, n² 2. Brasília: Ministério da Saúde; 2015.

11. Ministério da Saúde (Brasil). Gestão da Atenção Básica: ações da gestão para qualificação das equipes. Retratos da Atenção Básica, $n^{\circ} 2$. Brasília: Ministério da Saúde; 2015.

12. Vasconcelos IAL, Sousa MF, Santos LMP. Evolução do quantitativo de nutricionistas na Atenção Básica do Brasil: a contribuição dos Núcleos de Apoio à Saúde da Família e da Estratégia Saúde da Família de 2007 a 2013. Rev Nutr. 2015;8(4):431-50. https://doi.org/10.1590/1415-5 2732015000400009

13. Sumar N, Fausto MCR. Atenção Primária à Saúde: a construção de um conceito ampliado. J Manag Prim Health Care. 2014;5(2):202-12.

14. Ministério da Saúde (Brasil). Política Nacional de Alimentação e Nutrição. Brasília: Ministério da Saúde; 2012.

15. Ministério da Saúde (Brasil). Diretrizes do NASF: Núcleo de Apoio a Saúde da Família. Série B. Textos Básicos de Saúde, Cadernos de Atenção Básica, n² 27. Brasília: Ministério da Saúde; 2009.

16. Camossa ACA, Telarolli Junior R, Machado MLT. O fazer teórico-prático do nutricionista na estratégia saúde da família: representações sociais dos profissionais das equipes. Rev Nutr. 2012;25(1):89-106. https://doi.org/10.1590/S1415-5 2732012000100009

17. Pimentel VRM, Sousa MF, Hamann EM, Mendonça AVM. Alimentação e nutrição na Estratégia Saúde da Família em cinco municípios brasileiros. Ciênc Saúde Coletiva. 2014;19(1):49-57. https://doi. org/10.1590/1413-81232014191.1901

18. Aguiar CB, Costa NMSC. Formação e atuação de nutricionistas dos Núcleos de Apoio à Saúde da Família. Rev Nutr. 2015;28(2):207-16. https://doi. org/10.1590/1415-52732015000200009

19. Mesquita Filho M, Luz BSR, Araújo CS. A Atenção Primária à Saúde e seus atributos: a situação das crianças menores de dois anos segundo suas cuidadoras. Ciênc Saúde Coletiva. 2014;19(7):2033-46. https://doi.org/10.1590/14 13-81232014197.17322013

20. Ricardi LM, Sousa MF. Educação permanente em alimentação e nutrição na Estratégia Saúde da Família: encontros e desencontros em municípios 
brasileiros de grande porte. Ciênc Saúde Coletiva. 2015;20(1):209-18. https://doi.org/10.1590/1413-8 1232014201.20812013

21. Pinheiro $A R O$, Recine $E$, Alencar $B$, Fagundes AA, Sousa JS, Monteiro RA, et al. Percepção de professores e estudantes em relação ao perfil de formação do nutricionista em saúde pública. Rev Nutr. 2012;25(5):631-43. https://doi.org/10.1590/ S1415-52732012000500008

22. Cervato-Mancuso AM, Tonacio LV, Silva ER, Vieira VL. A atuação do nutricionista na Atenção Básica à Saúde em um grande centro urbano. Ciênc Saúde Coletiva. 2012;17(12):3289-300. https:// doi.org/10.1590/S1413-81232012001200014

23. Borelli M, Domene SMA, Mais LA, Pavan J, Taddei JAAC. A inserção do nutricionista na Atenção Básica: uma proposta para o matriciamento da atenção nutricional. Ciênc Saúde Coletiva. 2015;20(9):2765-78. https://doi.org/10.1590/14 13-81232015209.13902014

24. Azeredo CM, Cotta RMM, Silva LS, Franceschini SCC, Sant'Ana LFR, Lamounier JA. A problemática da adesão na prevenção da anemia ferropriva e suplementação com sais de ferro no município de Viçosa (MG). Ciênc Saúde Coletiva. 2013;18(3):827-36. https://doi.org/10.1590/S141 3-81232013000300028

25. Pedraza DF. Growth surveillance in the context of the Primary Public Healthcare Service Network in Brazil: Literature review. Rev Bras Saúde Matern Infant. 2016;16(1):7-19. https://doi.org/10.15 90/18 06-93042016000100002
26. Rodrigues EM, Nascimento RG, Araújo A. Protocolo na assistência pré-natal: ações, facilidades e dificuldades dos enfermeiros da Estratégia de Saúde da Família. Rev Esc Enferm USP. 2011;45(5):1041-7. https://doi.org/10.1590/S008 0-62342011000500002

27. Venancio SI, Costa Rosa TE, Bersusa AAS. Atenção integral à hipertensão arterial e diabetes Mellitus: implementação da Linha de Cuidado em uma região de saúde do estado de São Paulo, Brasil. Physis. 2016;26(1):113-35.

28. Venancio SI, Giugliani ERJ, Silva OLO, Stefanello J, D’Aquino Benicio MH, Reis MCG, et al. Associação entre o grau de implantação da Rede Amamenta Brasil e indicadores de amamentação. Cad Saúde Pública. 2016;32(3):e00010315. https://doi.org/10. 1590/S0103-73312016000100008

29. Ministério da Saúde (Brasil). Gestão da Atenção Básica: insumos e medicamentos nas Unidades Básicas de Saúde. Retratos da Atenção Básica, $n^{\circ}$ 2. Brasília: Ministério da Saúde; 2015.

30. Lima CA, Oliveira APS, Macedo BF, Dias OV, Costa SM. Relação profissional-usuário de saúde da família: perspectiva da bioética contratualista. Rev Bioét. 2014;22(1):152-60. https://doi.org/10.15 90/S1983-80422014000100017

Received: June 8, 2017

Final version: September 5, 2017 Approved: September 22, 2017 